\title{
Board Diversity and Financial Performance: A GRAPHICAL TIME-SERIES APPROACH
}

\author{
Cobus CH Taljaard, Michael JD Ward and Chris J Muller \\ Gordon Institute of Business Science, University of Pretoria \\ Accepted: April 2015
}

\begin{abstract}
Directors need to guide and govern companies on behalf of and for the benefit of shareholders and stakeholders. However questions remain as to whether boards with higher levels of diversity amongst directors are better equipped to fulfil their fiduciary duty than boards with lower levels of diversity. This research examines whether increased levels of diversity within boards are associated with improved financial performance to shareholders. From the literature, several theoretical frameworks that could explain why increased diversity might or might not lead to improved board performance were noted. Share returns and directors' demographic data were collected for a sample of the largest 40 companies listed on the JSE from 2000 to 2013. This data was analysed using Muller and Ward's (2013) investment style engine by forming portfolios of companies based on board-diversity constructs. Time-series graphs of cumulative portfolio market returns were analysed to determine if the diversity dimensions tested were associated with improved share performance. The results show that racial diversity within boards is not associated with financial performance. However, increased gender diversity and younger average board age are shown to have strong associations with improved share price performance. These findings are mainly attributed to agency-, resource dependency, human capital and signalling theories. Increased diversity is seen to bolster independence and lessen agency problems. Rising diversity levels also enlarge boards' external networks, allowing diverse stakeholders' needs to be accommodated and limiting dependence on strategic resources. Finally, as human capital is increased, the collection of different skills and experiences are associated with better performance. The results, based on a more robust methodology and improved data set, provide additional support to previous studies.
\end{abstract}

Key words: boards, diversity, financial performance

JEL: J240, L250, M100, 500

\section{$1 \quad$ Introduction}

The aim of this research is to investigate if company share price performance is influenced by diversity amongst board members.

There is no clear consensus in the literature reviewed as to whether increased levels of diversity amongst board members contribute to improved company financial performance. Behavioural and psychological theory suggests that increased diversity would allow for a broader perspective and improved fiduciary role of boards, but the empirical evidence is not so clear.

Our objectives are to establish whether increased diversity amongst board members of listed companies can be associated with improved share price performance and to determine which diversity dimensions have the strongest association with improved performance.

In general, previous studies have relied on limited data sets and company- or industry- specific analytical methodologies. This study employs both an improved methodology, as well as an extended dataset, to determine in a more robust manner if there is indeed an association between increased levels of diversity within boards and improved company financial performance.

\section{Literature review}

The South African legal and best practice framework of board duties and the King III Report ("Duties of directors," 2011) concur with Adams, Hermalin \& Weisbach (2010) that directors" duties are mainly: to serve as advisors to the CEO and top management; set strategy; assess management performance; guide the appointment and retrenchment of executive managers and 
promote the interests of shareholders. Within this mandate, we examine the theory and existing literature to determine which dimensions of diversity could contribute to effective board operation and superior company financial performance.

Hafsi and Turgut state that "the precise meaning of boardroom diversity is still unclear" (2013:463). They define two constructs of board diversity; namely structural diversity amongst different boards; and demographic diversity within boards. Diversity amongst boards refers to dissimilarities in board characteristics; for example "size, leadership structure (duality of chairman and CEO), founder leader as director, the presence and number of international directors, nature and operations of board committees, board independence, director ownership, director tenure, and director compensation" (Hafsi \& Turgut, 2013:464). Diversity within boards refers to dissimilarities between directors and has been categorised between directly observable (demographic) and less visible (cognitive) dimensions (Erhardt, Werbel \& Shrader, 2003; Mahadeo Soobaroyen \& Hanuman, 2012; Marimuthu, 2008). Definitions of demographic dimensions include gender, age and ethnicity for example, whilst cognitive dimensions include educational background and political ideology. Listed below in

Table 1, in descending order of frequency of mention, are the accumulated dimensions of diversity gleaned from the literature:

Table 1

Dimensions of diversity noted in previous studies

\begin{tabular}{|c|c|c|}
\hline Dimension of diversity & Diversity construct & Referenced in \\
\hline Gender & $\begin{array}{l}\text { Diversity within } \\
\text { boards: demographic }\end{array}$ & $\begin{array}{l}\text { (Carter, D’Souza, Simkins \& Simpson, 2010; Dezsö \& Ross, 2012; Hili \& } \\
\text { Affes, 2012; Jhunjhunwala \& Mishra, 2012; Larkin, Bernardi \& Bosco, } \\
\text { 2012; Lückerath-Rovers, 2013; Mahadeo et al., 2012; Miller \& del Carmen } \\
\text { Triana, 2009; Nguyen, Locke \& Reddy, 2012; Shukeri, Shin \& Shaari, } \\
\text { 2012; Van-Ness, Miesing \& Kang, 2010; Yasser, 2012) }\end{array}$ \\
\hline Independence / Duality & $\begin{array}{l}\text { Diversity amongst } \\
\text { boards }\end{array}$ & $\begin{array}{l}\text { (Dalton, Daily, Ellstrand \& Johnson, 1998; Dalton \& Dalton, 2011; } \\
\text { Mahadeo et al., 2012; Rhoades, Rechner \& Sundaramurthy, 2000; } \\
\text { Shukeri et al., 2012; Van-Ness et al., 2010) }\end{array}$ \\
\hline Race or Ethnicity & $\begin{array}{l}\text { Diversity within } \\
\text { boards: demographic }\end{array}$ & $\begin{array}{l}\text { (Carter et al., 2010; Erhardt et al., 2003; Marimuthu, 2008; Miller \& del } \\
\text { Carmen Triana, 2009; Shukeri et al., 2012) }\end{array}$ \\
\hline Age & $\begin{array}{l}\text { Diversity within } \\
\text { boards: demographic }\end{array}$ & $\begin{array}{l}\text { (Jhunjhunwala \& Mishra, 2012; Mahadeo et al., 2012; Van-Ness et al., } \\
\text { 2010) }\end{array}$ \\
\hline Tenure & $\begin{array}{l}\text { Diversity amongst } \\
\text { boards }\end{array}$ & (Jhunjhunwala \& Mishra, 2012; Van-Ness et al., 2010) \\
\hline Nationality & $\begin{array}{l}\text { Diversity within } \\
\text { boards: demographic }\end{array}$ & (Jhunjhunwala \& Mishra, 2012; Nielsen \& Nielsen, 2013) \\
\hline Experience & $\begin{array}{l}\text { Diversity within } \\
\text { boards: cognitive }\end{array}$ & (Jhunjhunwala \& Mishra, 2012; Van-Ness et al., 2010) \\
\hline Educational background & $\begin{array}{l}\text { Diversity within } \\
\text { boards: cognitive }\end{array}$ & (Jhunjhunwala \& Mishra, 2012; Mahadeo et al., 2012) \\
\hline Political ideology & $\begin{array}{l}\text { Diversity within } \\
\text { boards: cognitive }\end{array}$ & (Kim, Pantzalis \& Park, 2013) \\
\hline
\end{tabular}

Source: Own observations

Some studies found links between increased diversity and company performance (Kim et al., 2013; Nielsen \& Nielsen, 2013), while others found no clear association (Jhunjhunwala \& Mishra, 2012; Mahadeo et al., 2012) and still others have indicated that increased levels of diversity could be harmful to company performance (Carter, D'Souza, Simkins \& Simpson, 2010; Jhunjhunwala \& Mishra, 2012; Nielsen \& Nielsen, 2013).

A variety of theories have been put forward in literature as to why diversity within boards could be associated with enhanced board and company performance. Below in Table 2, listed in descending order from most frequently ascribed, are the main theories encountered in the literature.

To understand which of these theories might support the outcomes of the planned research, each was reviewed. 
Table 2

Theories regarding the benefits of diversity

\begin{tabular}{|c|c|}
\hline Theory & Referenced in \\
\hline $\begin{array}{l}\text { Agency theory linked to board } \\
\text { independence and distinct viewpoints }\end{array}$ & $\begin{array}{l}\text { (Bosner, 2007; Campbell \& Mínguez-vera, 2008; Carter et al., 2010; Dalton et al., } \\
\text { 1998; Dalton \& Dalton, 2011; Hafsi \& Turgut, 2013; Hili \& Affes, 2012; Khan \& } \\
\text { Vieito, 2013; Kim et al., 2013; Mahadeo et al., 2012; Nguyen et al., 2012; } \\
\text { Rhoades et al., 2000; Rodríguez-Domínguez, García-Sánchez \& Gallego-Álvarez, } \\
\text { 2012; Shukeri et al., 2012; Van-Ness et al., 2010) }\end{array}$ \\
\hline $\begin{array}{l}\text { Resource dependency theory including } \\
\text { consideration of company reputation } \\
\text { and sensitivity to stakeholder needs }\end{array}$ & $\begin{array}{l}\text { (Carter et al., 2010; Hafsi \& Turgut, 2013; Hili \& Affes, 2012; Larkin et al., 2012; } \\
\text { Lückerath-Rovers, 2013; Miller \& del Carmen Triana, 2009; Nguyen et al., 2012; } \\
\text { Rodríguez-Domínguez et al., 2012; Srinidhi, Gul \& Tsui, 2011; Yasser, 2012) }\end{array}$ \\
\hline $\begin{array}{l}\text { Human capital theory with reference to } \\
\text { improved information and decision } \\
\text { making leading to increased innovation }\end{array}$ & $\begin{array}{l}\text { (Carter et al., 2010; Dezsö \& Ross, 2012; Erhardt et al., 2003; Hafsi \& Turgut, } \\
\text { 2013; Jhunjhunwala \& Mishra, 2012; Lückerath-Rovers, 2013; Marimuthu, 2008; } \\
\text { Miller \& del Carmen Triana, 2009; Shukeri et al., 2012; Srinidhi et al., 2011) }\end{array}$ \\
\hline Upper echelons theory & (Dezsö \& Ross, 2012; Nielsen \& Nielsen, 2013; Yasser, 2012) \\
\hline Signalling theory & (Miller \& del Carmen Triana, 2009) \\
\hline Institutional theory & (Nielsen \& Nielsen, 2013) \\
\hline Behavioural theory of the firm & (Miller \& del Carmen Triana, 2009) \\
\hline
\end{tabular}

Source: Own observations

\subsection{Agency theory}

A recent paper commented on the value of diversity amongst directors and indicated that "the positive relationship between board diversity and financial performance is predicted by both agency theory and resource dependence theory" (Nguyen, Locke \& Reddy 2012:5). Hafsi and Turgut (2013:464) state that "Agency theory has emphasized the board's control function, and prescribed in particular both independence of the board from management and leadership structure duality or separation of the functions of CEO and chairman of the board".

Bryant and Davis (2012) describe agency theory along the following lines: because an organisation's representatives or agents, for instance its management, act on behalf of the organisation, and because agents' interests are never fully aligned with those of the organisation, agents would experience conflicts of interest in some situations and would act in their own selfinterest unless controlled or incentivised to act in line with those of the organisation. Fiduciary functions have been introduced by organisations to counter the effects of misaligned interests. Agency theory substantiates the argument for board independence to "reduce the likelihood that the agenda and initiatives will be dominated by the CEO" (Kim et al., 2013:223). Diversity within boards can be seen as a way of increasing board independence and ensuring a broad base of balanced interests, resulting in improved control and alignment of interests.

\subsection{Resource dependency theory}

Nguyen et al. (2012) describe resource dependency theory as an association between board constructs (such as size and diversity) and the "security of firms' vital resources", including aspects such as the firms' "prestige and legitimacy" (Nguyen et al., 2012:5). Bryant and Davis (2012) point out that resource dependency theory asserts that organisations act in ways relevant to their dependence on certain resources. Organisations respond to cues from their external environment in order to reduce their dependence on, and maintain independence over relevant resources. Organisations that cope better with uncertainty and are able to reduce uncertainty for their stakeholders and which have control over scarce resources and the substitutability of their controlled resources, have a competitive advantage.

Expanding this view, Hafsi and Turgut (2013:464) state that in terms of board composition, "diversity is desired by customers and other stakeholders for whom it is a demonstration of management sensitivity to stakeholders' preferences, aspirations, and concerns". Bryant and Davis (2012) indicate that more diverse boards would have better access to information and networks to assist with achieving organisational goals in terms of the resource dependency theory by increasing "the ability to cope with uncertainty and minimize uncertainty" (2012:6). 


\subsection{Human capital theory}

Carter et al. (2010) summarise human capital theory as an organisation's view and utilisation of employees' experience, skills and education for its benefit. When diversity within boards increases, directors "having unique human capital" (Carter et al., 2010:398) increase, because different individuals have different human capital attributes. Increased diversity within boards is therefore seen as a way to increase the range of unique human capital aspects represented, leading to enhanced decision- making abilities and greater innovation (Hafsi \& Turgut, 2013).

\subsection{Signalling theory}

Signalling theory has its roots in economics and is used to explain the conduct between two or more groups that have access to different information, also known as information asymmetry. Signalling theory primarily involves strategies and actions used to reduce information asymmetry between stakeholders (Connelly, Certo, Ireland \& Reutzel, 2011). Connelly et al. also mention that signalling theory is used to "explain how firms use heterogeneous boards to communicate adherence to social values to a range of organizational stakeholders" (2011:40). Signalling theory "posits that firms use visible signals to gain reputation and status among the public" (Miller \& del Carmen Triana, 2009:756) and that "due to information asymmetries, the public often uses both actions and symbols to judge a firm's reputation and quality" (Miller \& del Carmen Triana, 2009:762). Organisations therefore intentionally (or even unintentionally) signal intent to the market, based on the composition of their boards. Accordingly, it is argued that higher levels of diversity within boards are seen by an organisation's stakeholders as indicative of the organisation's desire to incorporate diverse interests and opinions into governance processes and ultimately into strategic and operational actions which will enhance performance.

\subsection{Institutional theory}

Institutional theory highlights normative aspects of the context in which organisations operate. Yang Yang \& Konrad (2011:12-13) hold/state that "[b]y adopting structures that conform to institutional requirements, organizations demonstrate their conformity to social norms and thereby garner legitimacy for their operations". Whereas signalling theory assumes organisations are sending signals to stakeholders by the composition of their boards, institutional theory assumes the opposite: stakeholders or institutions directly or indirectly pressurise organisations to conform to their requirements. Yang Yang and Konrad (2011) refer to three types of institutions; namely regulative, normative and cognitive. Regulative includes legal and regulatory institutions; normative includes social and professional norms; and cognitive includes ethics and culture. Three types of pressure are described, namely coercive, normative and mimetic. Coercive pressures occur due to "societal expectations and interorganization interdependence" (Yang Yang \& Konrad, 2011:12); normative from professionalisation; and mimetic from ambiguity in the environment.

Nielsen and Nielsen (2013) use institutional theory to explain how cognitive diversity within boards relates to the societal context of different countries and cultures. It was deduced from the literature review that institutional theory might have been addressed in other studies through an inclusive view of resource dependency theory and human capital theory. In both of those theories, education, skills and experience have allowed board members to incorporate experiences from their diverse networks to cater to social and institutional requirements and reduce ambiguity or uncertainty. It would seem that in terms of the association between diversity within boards and company financial performance, institutional theory does not provide reasons for having a competitive advantage. Rather, it appears to describe necessary conditions for operating within a given environment; a "ticket to the game" as such.

\subsection{Behavioural theory of the firm}

Behavioural theory of the firm describes processes within firms and how interactions between various groups or individuals contribute to decisions (Gavetti, Greve, Levinthal \& Ocasio, 2012). 
Argote and Greve (2007:339) state that "Key concepts and mechanisms discussed in A behavioral theory of the firm are bounded rationality, problemistic search, the dominant coalition, standard operating procedures, and slack search". They also say that the book referred to in their statement above (A behavioral theory of the firm), does not introduce a theory of firm behaviour, but rather that it sets the platform for researchers to develop various theories based on "different assumptions and deriving different predictions" (Argote \& Greve, 2007:337). As such, it does not add a significantly different theme to the diversity debate if read against the background of the broader themes from the agency-, resource dependency- and human capital theories.

Key themes exposed through the literature review can be grouped into: increased independence and improved monitoring; increased number of diverse viewpoints; increased creativity; increased access to extended networks; and greater access to information. Many authors however note that board effectiveness and company performance can be compromised by increased internal diversity if boards do not operate as effective functioning teams (Adams et al., 2010; Erhardt et al., 2003; Jhunjhunwala \& Mishra, 2012; Lückerath-Rovers, 2013; Marimuthu, 2008; Miller \& del Carmen Triana, 2009; Rodríguez-Domínguez et al., 2012).

Three unpublished South African master's studies (Matlala, 2011; Lehobo, 2011 and Swartz, 2006) all used company financial ratios to evaluate company performance in terms of board diversity. Two used only cross-sectional analyses and the one longitudinal study was limited to only 5 years of data. The validity of their findings was compromised by sampling issues, survivor bias and methodological limitations, and their results were mostly negative or inconclusive.

In conclusion, various behavioural theories can be linked to improved organisational financial performance based on progressive diversity amongst board members. Various hypotheses are formulated to cater for different diversity dimensions and for combinations between these. From the literature and available data, a number of hypotheses are tested.

\section{Hypotheses}

\subsection{Gender}

$\mathrm{H}_{\mathrm{G} 0}$ : There is no association between the ratio of female to male representation on boards and company financial performance.

$\mathrm{H}_{\mathrm{G} 1}$ : There is an association.

\subsection{Race}

$\mathrm{H}_{\mathrm{R} 0}$ : There is no association between the level of racial diversity on boards and company financial performance.

$\mathrm{H}_{\mathrm{R} 1}$ : There is an association.

\subsection{Age}

$\mathrm{H}_{\mathrm{A} 0}$ : There is no association between the average age of boards and company financial performance.

$\mathrm{H}_{\mathrm{A} 1}$ : There is an association.

\subsection{Gender and age}

$\mathrm{H}_{\mathrm{GA} 0}$ : There is no association between the level of combined gender and age diversity on boards and company financial performance.

$\mathrm{H}_{\mathrm{GA} 1}$ : There is an association.

\section{Research methodology}

Proof of causality between diversity within boards and company financial performance has been elusive due to the numerous influences that cannot be accounted for or controlled in quantitative 
tests, leading to concerns regarding endogeneity. Some of these influences can be attributed to market sector or industry performance and market events such as the global financial crisis of 2008. Dezsö and Ross (2012) state that many studies on the topic do not "control for many observable factors that might influence firm performance" and "more importantly, fail to account for (a) the unobservable heterogeneity associated with particular firms or time periods that might simultaneously affect the level of female representation in top management and firm performance and (b) the related possibility of reverse causality" $(2012: 1073,1074)$.

Overcoming or compensating for some of these factors was of concern when adopting a research methodology. The methodology used in this research followed Muller and Ward's (2013) investment style research. Muller and Ward (2013) construct five equal weighted portfolios of shares, ranked by a variable under investigation or so-called investment "style". Each quarter the portfolios are reconstructed, based on changes in the ranking of the variable under investigation, and rebalanced within each portfolio. A time-series of the daily value of each portfolio is constructed.

Classic, static cross-sectional analyses provide only descriptive results for a given interval. Combined with longitudinal data and repeated portfolio reconstruction as described by Muller and Ward (2013), cross-sectional analyses can be successfully used as a quasi-experimental research design to quantify the degree of association of an independent variable through portfolio performance. For practical purposes, the use of portfolios of companies works to remove company-specific influences from the results as each reconstructed portfolio contains companies in a specific period, selected on the basis of the variable under investigation.

\subsection{Population and sampling}

The research design called for time series data of share returns and information on directors. Based on the data that were available in the investment style engine database (Muller \& Ward, 2013) the universe was initially defined as all companies ever listed on the JSE from 1985 to 2013. For practical reasons the number of companies to work with was reduced and the sample frame for this study was re-defined as companies continuously listed from 2000 to 2013 on the JSE's All Share Index (ALSI); a sample comprising 104 companies.

No longitudinal secondary data of board members could be sourced, and for practical reasons, since the historical data regarding directors and board composition had to be captured manually, the sample was further reduced. This was done by ranking the list of 104 companies by market capitalisation as at 31 January 2005 in descending order, and selecting the top 40 (Appendix 1). The sampling methodology introduced some survivorship bias, as only companies that were listed and traded continuously from 2000 to 2013 were considered.

A Microsoft Access database was created to store all the manually captured records of directors and their representation on different boards. The database contained details of directors' names, demographics, qualifications and board affiliation.Table 3 below summarises data captured regarding directors and boards after perusing the 523 annual reports of the selected 40 companies.

Table 3

Data captured in the research database

\begin{tabular}{|l|c|r|}
\hline \multicolumn{1}{|c|}{ Item logged } & Available & Manual \\
\hline Directors registered & 354 & 673 \\
\hline Qualifications registered & & 304 \\
\hline Company - annual report - director combinations & & 7258 \\
\hline Director - qualification combinations & & 2247 \\
\hline Total & 354 & 10482 \\
\hline
\end{tabular}

\subsection{Data analysis}

To rank diversity amongst different boards, diversity needed to be quantified in a standardised manner, and it was "defined as the collective amount of differences among members within a 
social unit" and "as the distribution of differences among the members of a unit with respect to a common attribute" (Solanas, Selvam, Navarro \& Leiva, 2012:412).

Three types of diversity and related indices were identified, namely separation, variety and disparity, which were defined as follows: "separation, variety, and disparity are respectively understood as differences in attitude or position, differences in categorical characteristics, and differences in power or status hierarchy", where "Blau's index, standard deviation, and coefficient of variation respectively correspond to measure diversity as variety, separation, and disparity" (Solanas et al., 2012:412).

Table 4

Different types of diversity and related indices

\begin{tabular}{|l|l|c|c|}
\hline \multicolumn{1}{|c|}{ Diversity type } & \multicolumn{1}{|c|}{ Examples } & \multicolumn{1}{c|}{ Diversity index } & Standard formula \\
\hline Separation & Age diversity & Standard deviation & $S D=\sqrt{\sum_{i-1}^{n} \frac{\left(x_{i}-\bar{x}\right)^{2}}{n}}$ \\
\hline Variety & Racial diversity & Blau's index & $B=1-\sum_{i=1}^{k} p_{i}^{2}$ \\
\hline Disparity & Income inequality & Coefficient of variation & $V=\frac{\sqrt{\sum_{i-1}^{n}\left(x_{i}-\bar{x}\right)^{2}-/ n}}{\bar{x}}$ \\
\hline
\end{tabular}

Source: Table based on Solanas et al. (2012:413)

Several univariate diversity indices were constructed based on gender, age, race and qualifications.

For gender, a categorical data set with only two categories, the ranking of boards was based on the proportion of women directors on the different boards. Blau's index was calculated as well, but that did not change the ranking and for simplicity in setting up test runs in the style engine, the percentage of women was used to rank boards in terms of gender diversity.

Some authors have quantified age diversity in terms of disparity with the coefficient of variation (Knight, Pearche, Smith, Olian, Sims, Smith \& Flood, 1999), but for this research, quantifying diversity or differences in the numerical data of directors' age was done through calculating the standard deviation in ages of boards because it suits situations where "the particular feature can be expressed in a metric way, e.g. age or organizational tenure" (Bertolt, 2009, para. 1). Differences between boards' age were quantified by the average age of the boards.

Quantifying racial diversity was done with Blau's index of diversity, because "If researchers wish to quantify the diversity of a group with regard to a nominal feature, such as ethnicity, gender, or education, they usually employ the Blau Index" (Bertolt, 2009, para. 2). Blau's index "measures the probability of two individuals chosen at random from the population being of different race or ethnicity" (Rushton, 2008:446). Blau's index is a true measure of diversity, as it takes into account how many different groups there are as well as how many individuals there are in each group. If all directors from a specific board were from the same race, that board would have a Blau's index of 0 per cent. If a board consisted of an equal number of directors from each of the seven races used in this study, the Blau's index would be 85.7 per cent. Concerns raised in the use of Blau's index for racial diversity analysis (Rushton, 2008) did not apply to this research, as the purpose was not to contrast differences between specific racial groups, but rather to identify degrees of racial diversity and not the types of racial diversity within and between boards.

A recent study on educational diversity and group effectiveness used separation- and variety diversity indices to quantify educational diversity (Curseu, Raab, Han \& Loenen, 2012). For this study's data analysis, the researchers used a slightly modified approach, as there were more educational categories per group and per person than in the study referred to above, as there were numerous directors that had multiple qualifications. To analyse this, two different approaches were followed. Firstly, similar to the study of Curseu et al. (2012), each director's highest level of qualification was used to calculate the educational level separation within each board by calculating the standard deviation of those levels. Secondly, the educational variety for each board 
was calculated with Blau's index by creating categories for each unique combination of educational family and NQF level.

Multidimensional diversity indices were also constructed by combining different univariate diversity dimensions into unique combinations and calculating Blau's index values for those newly formed categories. Two combinations were gender and race; and gender, race, age and education.

Board stability was not included in the literature review and was not seen to form part of the study. While collecting and analysing the data, the researchers wondered if the number of new directors on a board would not influence a board's effectiveness and in essence also be a form of diversity. A cursory review of literature indicated that the number of new group members did in fact have an impact on group performance (Koźlak, Zygmunt \& Nawarecki, 2013; McCarter \& Sheremeta, 2013). Tenure could not be calculated with data available, but board stability could. The stability of a group between two time periods was defined as the "quotient of the quantity of the set being the common part of the two sets which contain elements of this group in times t1 and t2 to the quantity of set being the sum of these sets" (Koźlak et al., 2013).

\subsection{Style engine data analysis}

Data was analysed and presented as a graphical time series with Muller and Ward's (2013) style engine. For univariate data analysis, equally weighted portfolios of shares were constructed, containing the same number of companies, after having ranked them according to the variable that was analysed. An example would be ranking companies by the percentage of women on their boards and equally dividing the companies into two portfolios of 20 companies each.

Bivariate data analysis was accomplished by ranking all the shares by each variable in turn and then selecting shares where variables were matched and opposed, resulting in four equally weighted portfolios, but not necessarily containing the same number of companies' shares, as shown in the example below, for 40 companies:

\begin{tabular}{|c|c|c|}
\hline & More women & Fewer women \\
\hline Older boards & 15 boards & 5 boards \\
\hline Younger boards & 5 boards & 15 boards \\
\hline
\end{tabular}

The style engine calculated the total return of each share in each portfolio on a daily basis, and updated the value of each portfolio, having started all portfolios from a base of 1 . Transaction costs that were related to the re-balancing in each portfolio were ignored, on the grounds that "it would be approximately the same between portfolios and immaterial" (Muller \& Ward, 2013:69). At monthly intervals, the portfolios' values were retained and the shares within each portfolio reselected according to the ranking methodology discussed. After rebalancing the portfolios, the daily portfolio value updating process continued, with each portfolio potentially containing a new set of ranked companies.

Muller and Ward's (2013) approach differs from traditional methodologies that evaluated results in terms of average returns per time period and tested for significance with t-tests. They viewed "the use of average monthly or quarterly returns as methodologically weak compared to cumulative returns, in much the same way as average abnormal returns reveal relatively little compared to cumulative abnormal returns in event studies" and proposed "to plot the cumulative index (value) of each portfolio over the timeframe and to visually compare the results" (Muller \& Ward, 2013:70). To assist interpretation of the plotted results, they divided the highest ranked portfolio's value by the lowest and plotted the resulting data series as a price-relative line. When the slope of this price-relative was upwards, the highest ranked portfolio performed better than the lowest, and vice-versa. A flat slope indicated that performance of the highest- and lowest ranked portfolios were the same. As a supplementary benchmark they showed "the market capitalisation weighted ALSI total return index (J203T) in the graph, and also the price-relative of the highest ranked portfolio against this" (Muller \& Ward, 2013:70). 


\section{Results}

Figure 1 below shows that the average size of boards in the sample increased marginally from about 13 in 2000 to 14 in 2012. The standard deviation decreased over this period, indicating that board sizes in the sample varied less over time. The left vertical axis represents the average number of directors per board and the right vertical axis the standard deviation of the number of directors per board.

Figure 1

Average board sizes

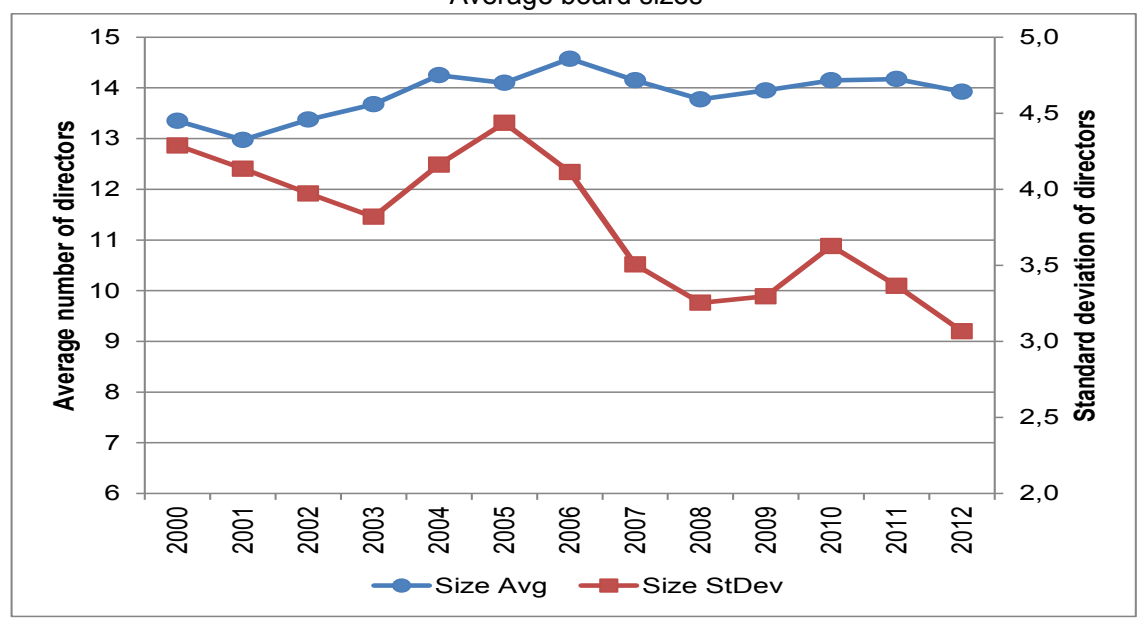

Figure 2 below shows that the average number of new directors per board has declined from two per company in 2000 to about one per company in 2012. An average board in the sample of 40 could have replaced all directors about every seven to eight years.

Figure 2

Average board stability

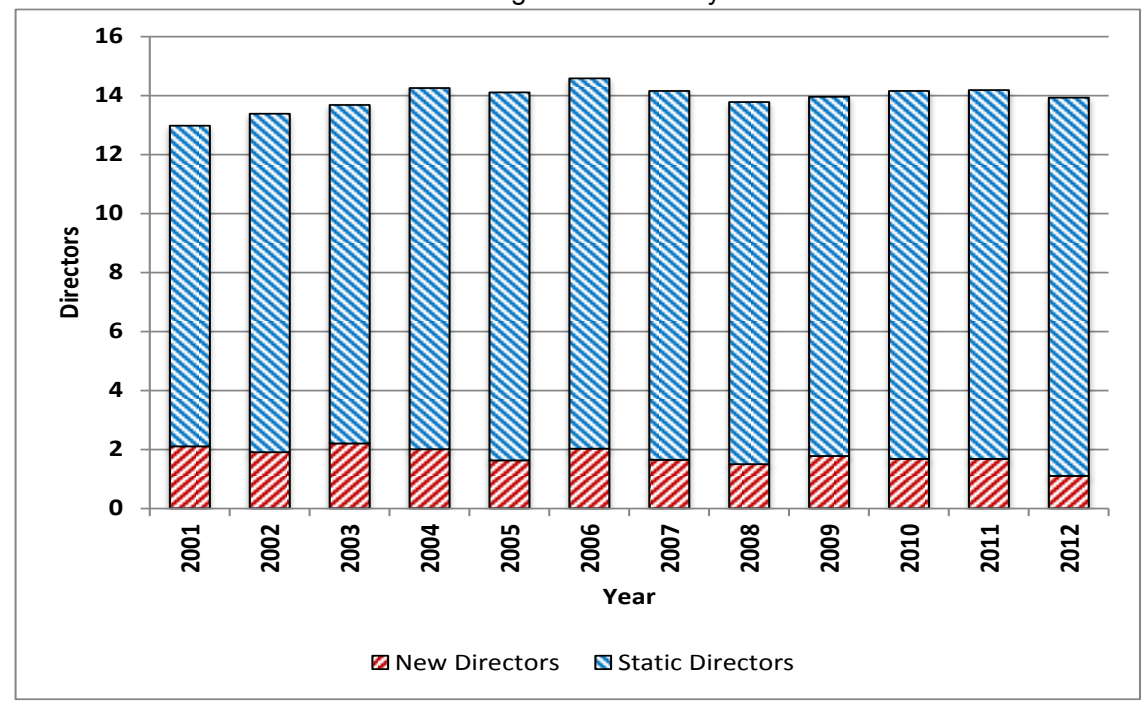


Figure 3 shows boards in the sample are ageing and that there was not a significant difference between the various boards' average ages.

Figure 3

Average age of board members

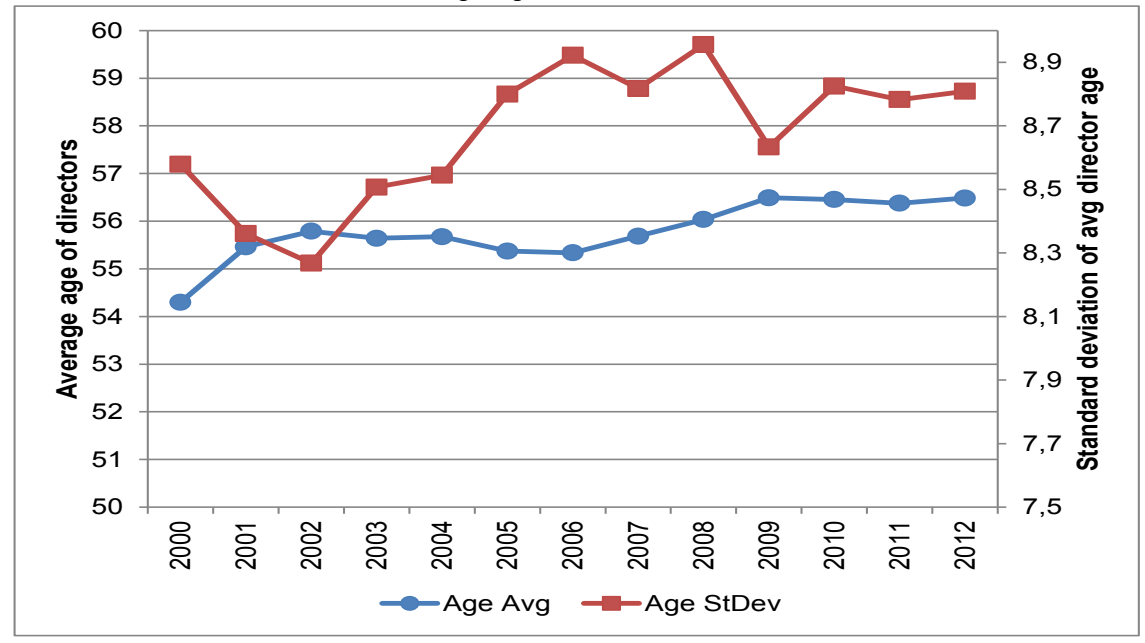

Figure 4 breaks the average board into decade age brackets for each year of the study period. It is interesting to note that the number of directors in their $70 \mathrm{~s}$ is increasing. This could be explained by the high level of board stability.

Figure 4

Average composition of board members' age

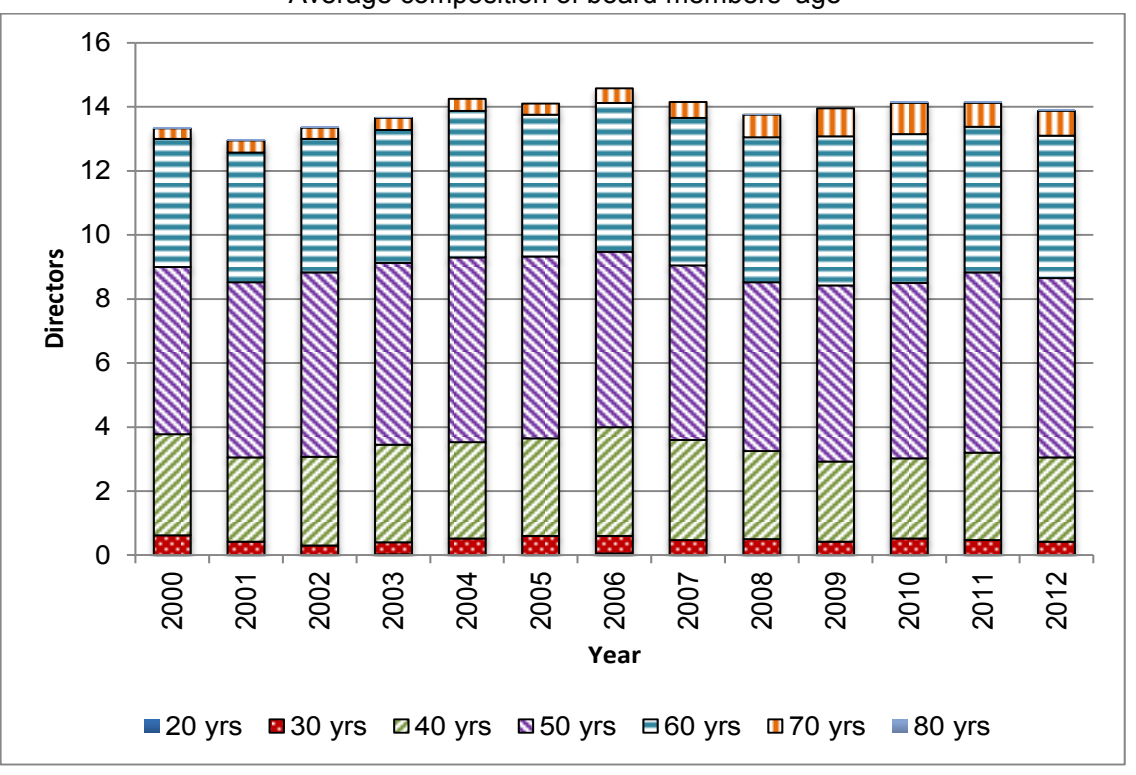


Although there were some concerns about the completeness and accuracy of the data, Figure 5 shows directors' highest qualification level. (The high number of directors shown with an NQF level 4 qualification is misleading as directors with no educational or qualification data were captured as having at least an NQF 4 level qualification.)

Figure 5

Average board highest qualification levels

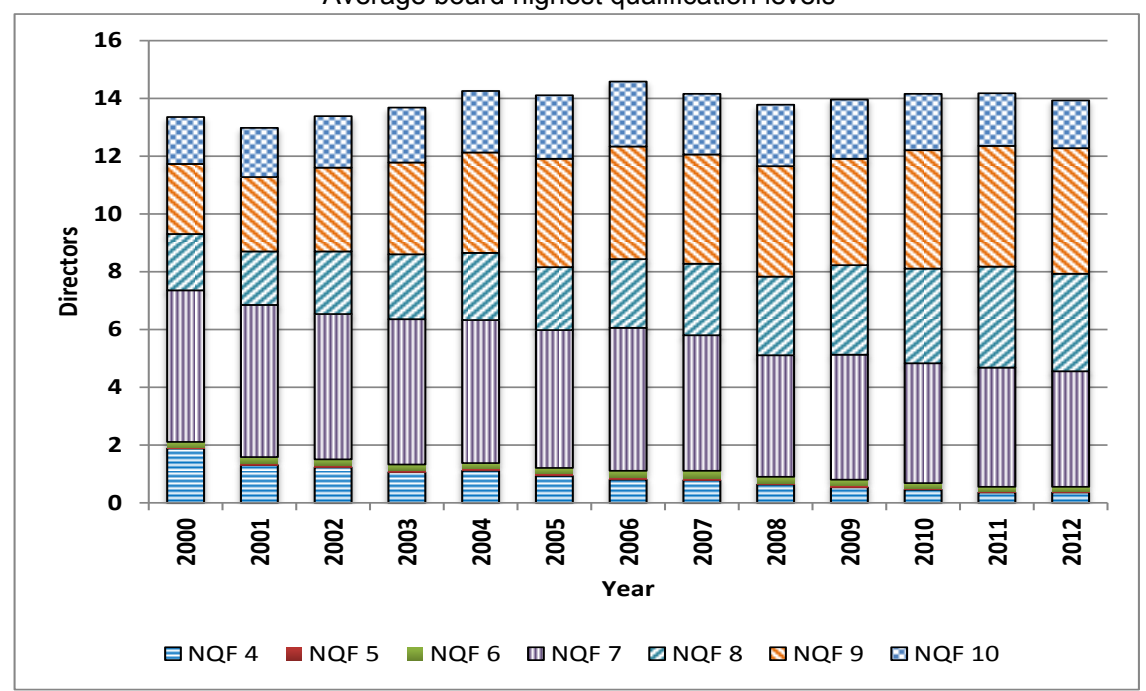

Figure 6 below indicates the average number of qualifications per board in the sample. (For legibility, some minor qualifications were omitted.) It is clear that the number of qualifications per board has increased and that the preferred qualifications for directors are in the economic and management sciences and accounting categories.

Figure 6

Average board qualifications

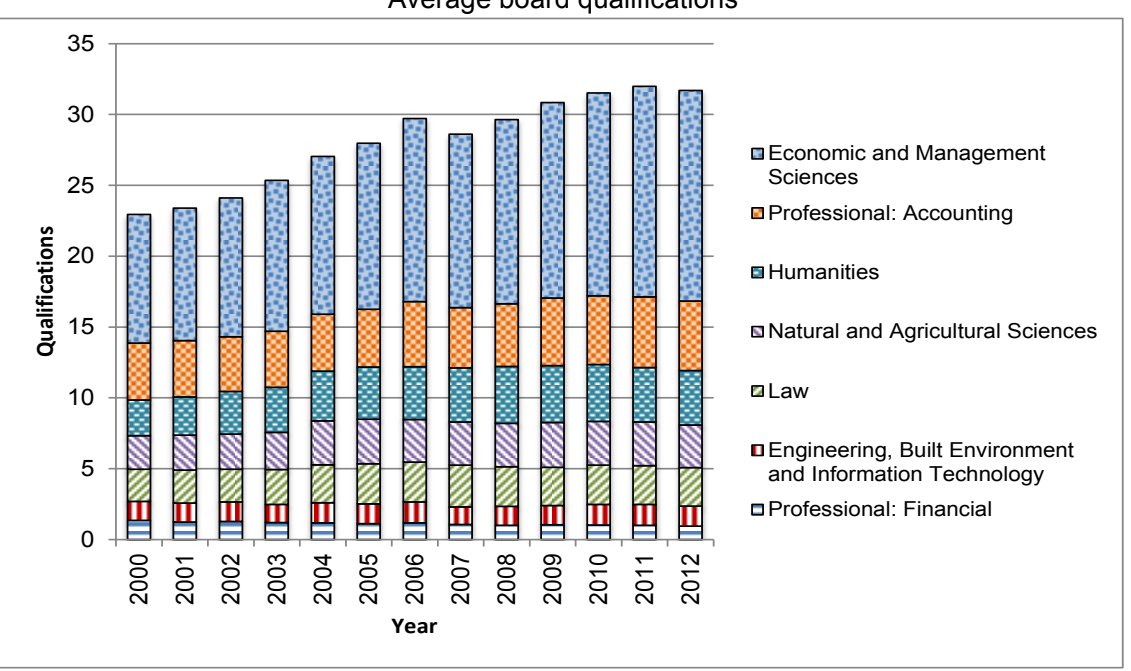


There has been a steady decline in the number of white directors on boards in the sample examined, as shown in Figure 7 below. This reflects the effects of the regulatory and social environment of post-apartheid South Africa, but indicates the long road ahead as the average racial representation on the boards in the sample of 40 companies in 2012 was 60 per cent white and only 30 per cent African.

Figure 7

Average board racial composition

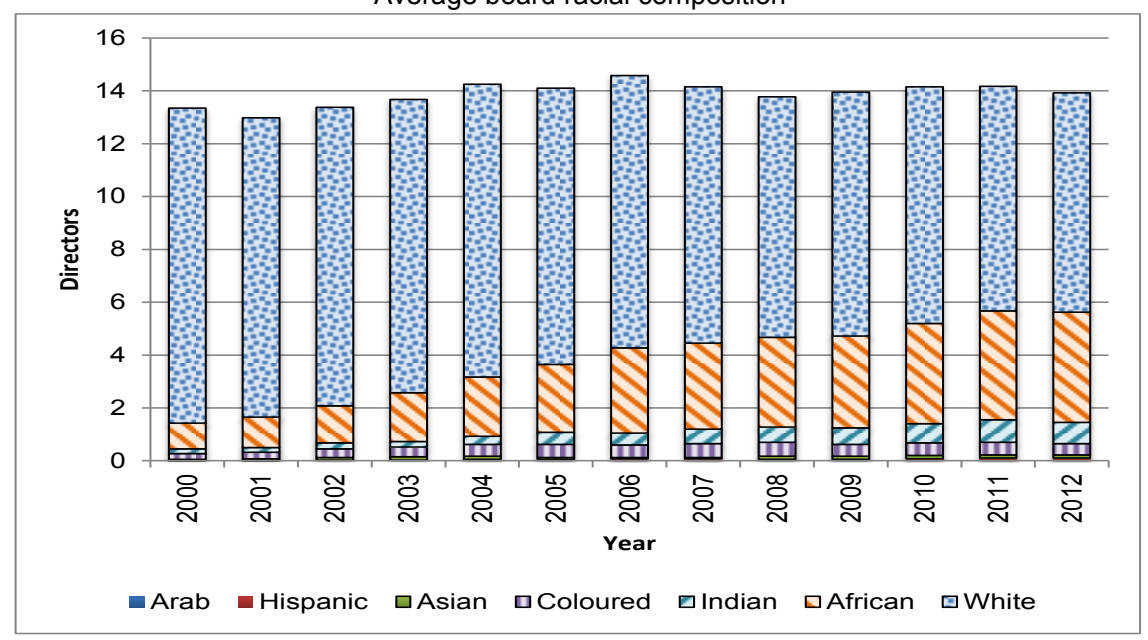

Figure 8 below illustrates a steady increase in the number of women serving on boards in the sample of 40 companies. The 2012 average of 2.8 women and 11.2 men however, still equates to an average female representation of only 20 per cent on the boards in the sample. Although based on a sample of 40 companies, this is assumed to be representative in terms of the sampling methodology used and illustrates an even bleaker scenario than the racial imbalance on boards. There might well be a need for a Women Empowerment and Gender Equality Bill (Xingwana, 2013).

Figure 8

Average board gender composition

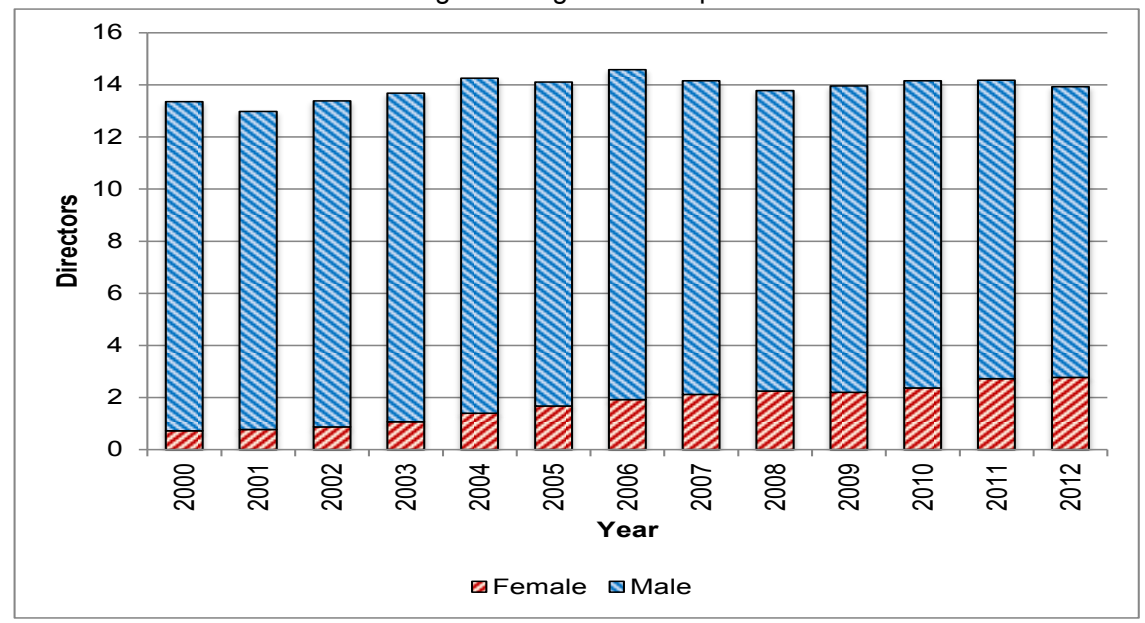


Figure 9a and 9b below combine the racial and gender composition data discussed above. Noteworthy is the female representation on boards: the number of African women on boards has increased significantly, closely keeping pace with the increase in the number of African male directors, while the number of white women serving on boards has been stable over the same period.

Figure 9a

Average board racial and gender composition for female directors

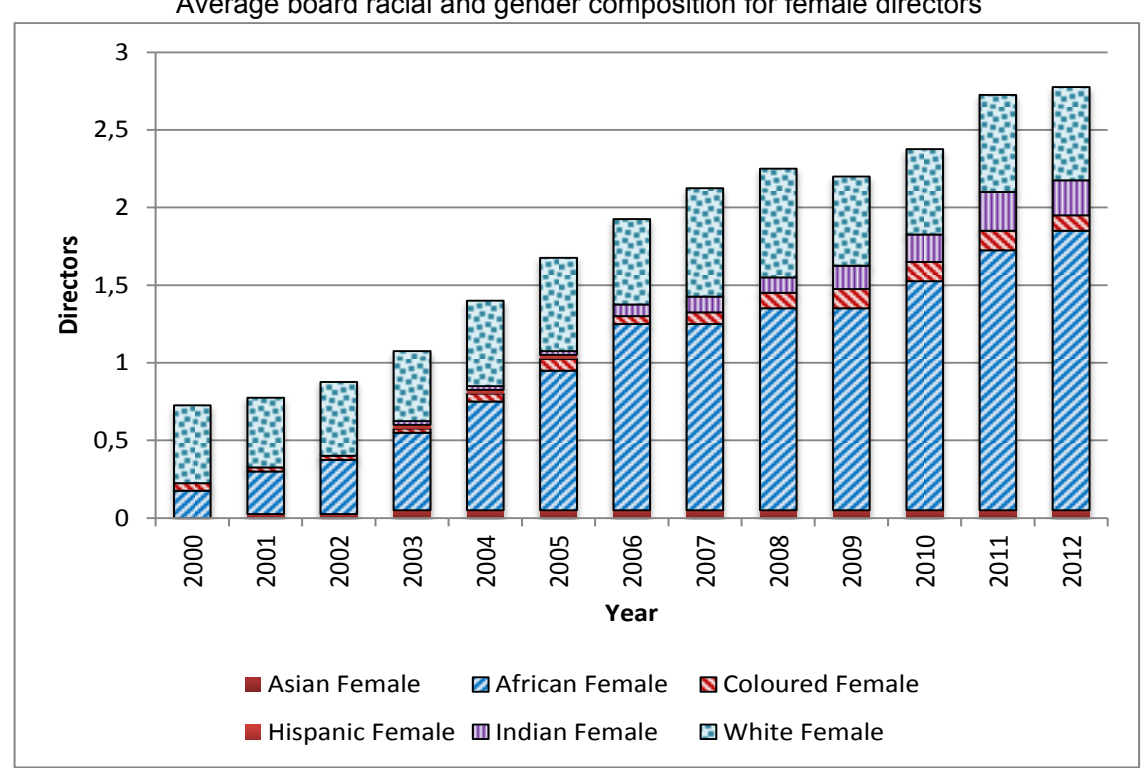

Figure $9 b$

Average board racial and gender composition for male directors

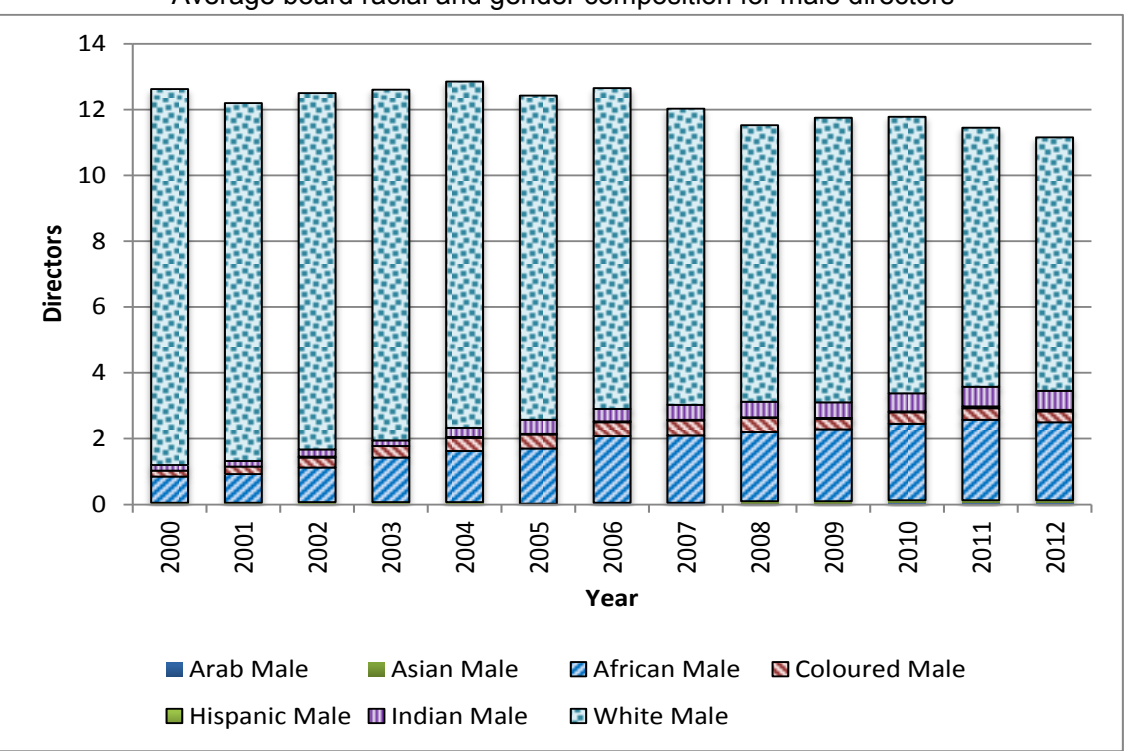




\subsection{Racial diversity and company financial performance}

Racial diversity was measured with Blau's index. Figure 10 below shows that the average racial diversity within boards for the selected sample has increased steadily and that the levels of racial diversity of the different boards is converging with more boards being increasingly racially diverse.

Figure 10

Average board Blau's index of racial diversity

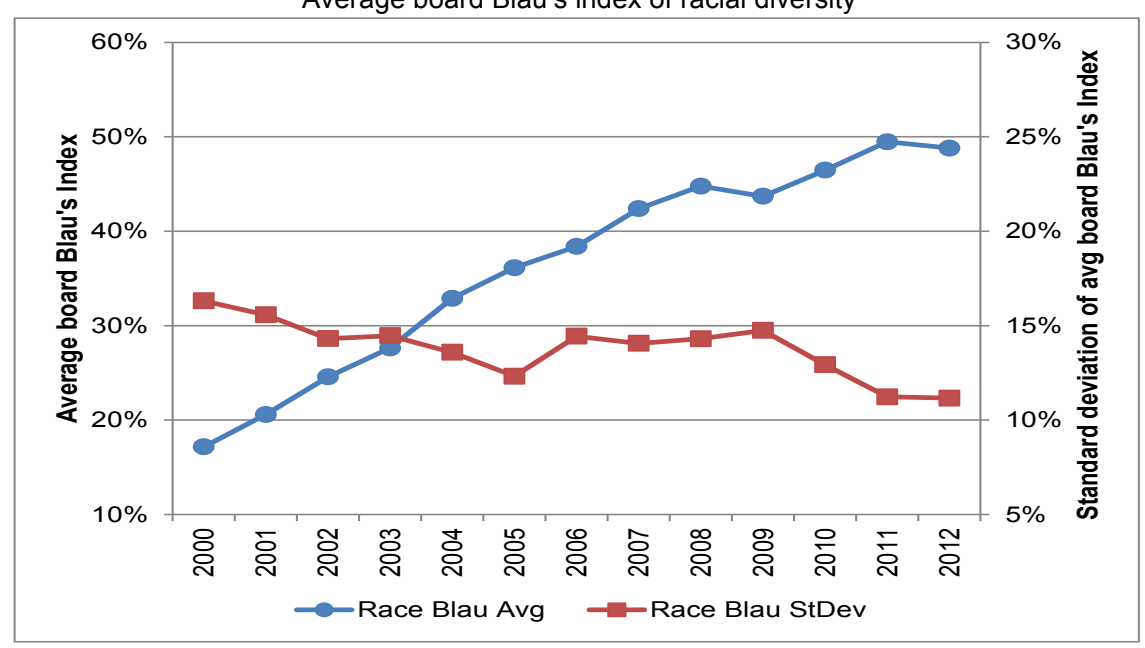

To test for association between racial diversity within boards and company financial performance, the 40 selected companies were ranked monthly in descending order according to their racial diversity index. This ranked list of companies was then divided into quintiles, each containing eight companies. The ranking was repeated monthly, and the portfolios re-balanced. In any given month the first quintile always contained the eight companies with the highest levels of diversity in that month, and the fifth quintile those with the lowest levels of diversity.

Figure 11 depicts the results as generated by the style engine. As this is the first chart of its kind in this paper, a brief explanation of its layout will be given before interpreting the results.

\section{Figure 11}

Results of racial diversity style engine analysis

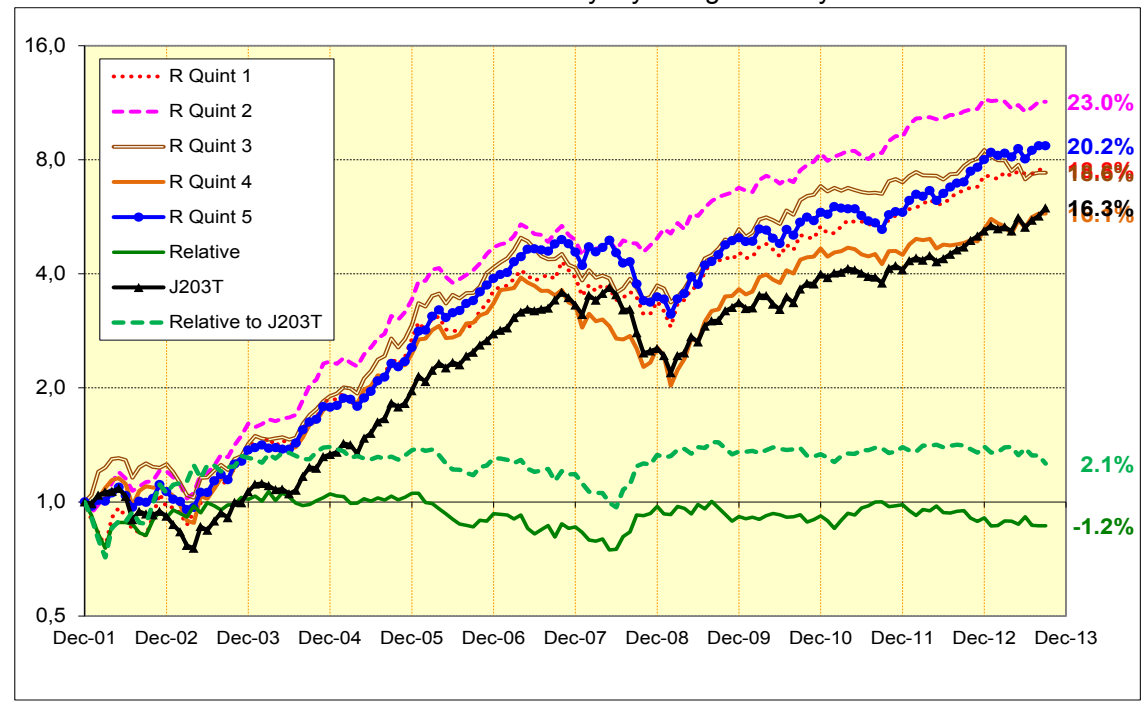


The horizontal axis indicates time and starts in 2001 because the different companies' annual reports were not all issued on the same date and allowance had to be made for all companies' results to be available at a starting date for analysis by the style engine.

- The vertical axis indicates cumulative portfolio values on a logarithmic scale with a base of two.

- Line graphs indicate the value of the quintile portfolios as discussed above, but also include the JSE's J203T (ALSI total return index in black with triangle value markers) as a benchmark. The two green line graphs at the bottom are relative measures, the first (solid line) comparing the first quintile portfolio's performance against the fifth quintile's and the latter (dashed) comparing the first quintile's portfolio performance against the J203T's. All line graphs are rebased to 1.00 at the start of the period.

- Data labels to the far right indicate the compound annual growth rate (CAGR) for each portfolio.

Interpreting the chart in terms of the association between the variable being tested and company financial performance was done by looking for noticeable differences in portfolio performance and at the order of the portfolios in terms of performance. If each portfolio's performance is ranked in the same order as the ranked quantiles, then there is a strong association. Figure 11 above illustrates limited outperformance by some portfolios, but in a random order. This indicates no clear association between diversity within boards and company financial performance. This is confirmed by the two relative line graphs on the chart, neither showing any clear trends and negligible performance differentials. We observe no association between racial diversity and company performance for the sample.

\subsection{Gender diversity and company financial performance}

To test for association between gender diversity within boards and company financial performance, all the boards in the sample were ranked monthly in descending order according to the level of female representation. This ranked list of companies was divided into quintiles, each containing eight companies.

Figure 12 below indicates the average percentage female representation in each of the five portfolios during the period under investigation.

Figure 12

Female representation within five gender-based portfolios

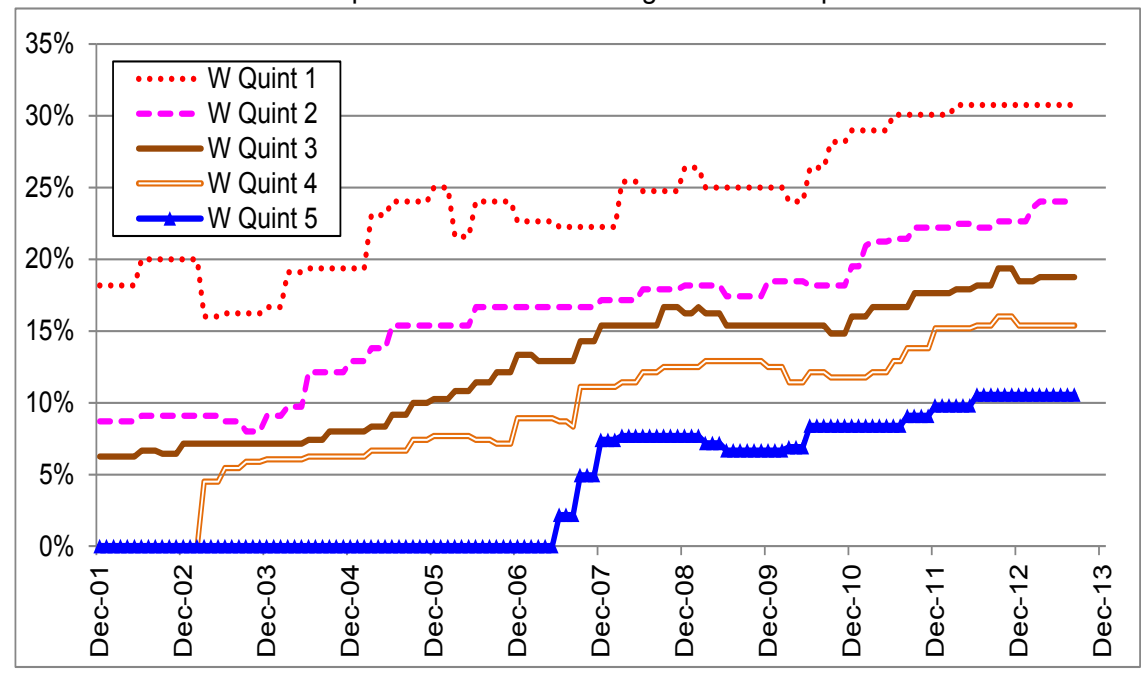


Figure 13

Results of gender diversity five-portfolio style engine analysis

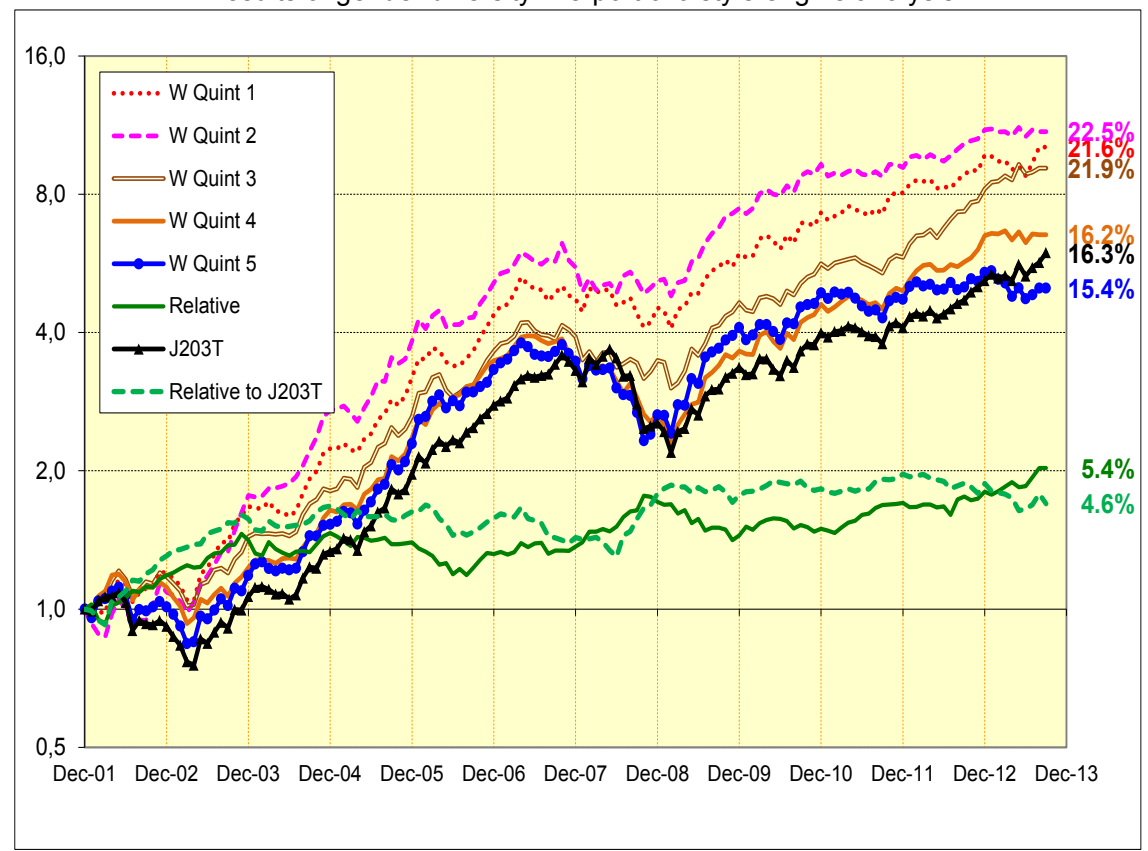

Figure 13 shows the results of analysing the five gender-ranked portfolios' performance. The results show two distinct groupings of ranked portfolio performance, with quintiles 2, 1 and 3 (in that order) out-performing quintiles 4 and 5. The green price relative line (solid line at bottom of chart) comparing the first and the last quintiles shows a fairly consistent upward trend. Although the portfolios' performance ranking is not in exactly the same order as the ranked variable, the two distinct groupings do indicate an association between gender diversity within boards and company financial performance. Ranked in terms of female representation on their boards, the top 60 per cent in the sample outperformed the bottom 40 per cent by about a 6 per cent CAGR. Companies with more women on their boards outperformed those with fewer. We do indeed observe an association between gender diversity within boards and company financial performance.

\subsection{Age diversity and company financial performance}

Age diversity is measured as the standard deviation of a group's age. In the light of further tests described later on in this report and for reviewers to relate more easily to the results, the average age of boards was used. This deviated from the initial intent of the research, as the average age of boards indicates diversity between boards and not within them. However, combined with other variables in bivariate analyses, the average age of boards can be used to illustrate the association of certain aspects of diversity with company performance.

The first quintile portfolio contained the eight companies that had the highest average age of board members in any given month, and the fifth portfolio the eight companies with the lowest average age. Figure 14 displays a significant difference between the first- and last quintile portfolios: the fifth quintile portfolio outperformed the first quintile portfolio by a CAGR of about eight per cent. Another interesting result is the marked grouping in performance results between the fourth and fifth quintile portfolios and those of the first to third quintiles. 
Figure 14

Results of style engine analysis on the average age of board members

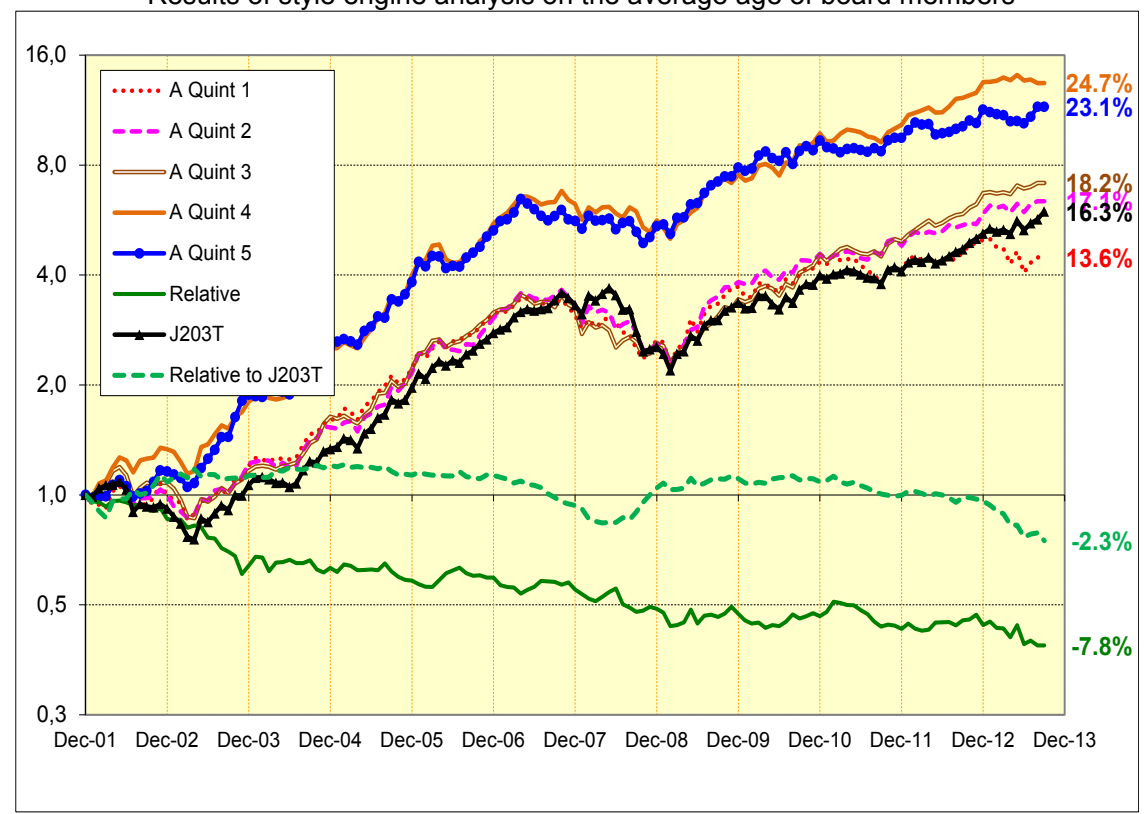

The green price relative (solid line at bottom of chart) between quintiles 1 and 5 shows a steady downward slope, indicating that the effect persisted over the 12-year analysis period. We observe that companies with younger boards performed better than those with older boards. This finding may contradict the notion that boards with more experience, indicated by higher average tenures or age, perform better.

\subsection{Age and gender diversity and company financial performance}

Combining gender and age variables into a bivariate cross-sectional analysis was the final analysis done with the style engine.

\section{Figure 15}

Results of style engine testing of gender diversity and age

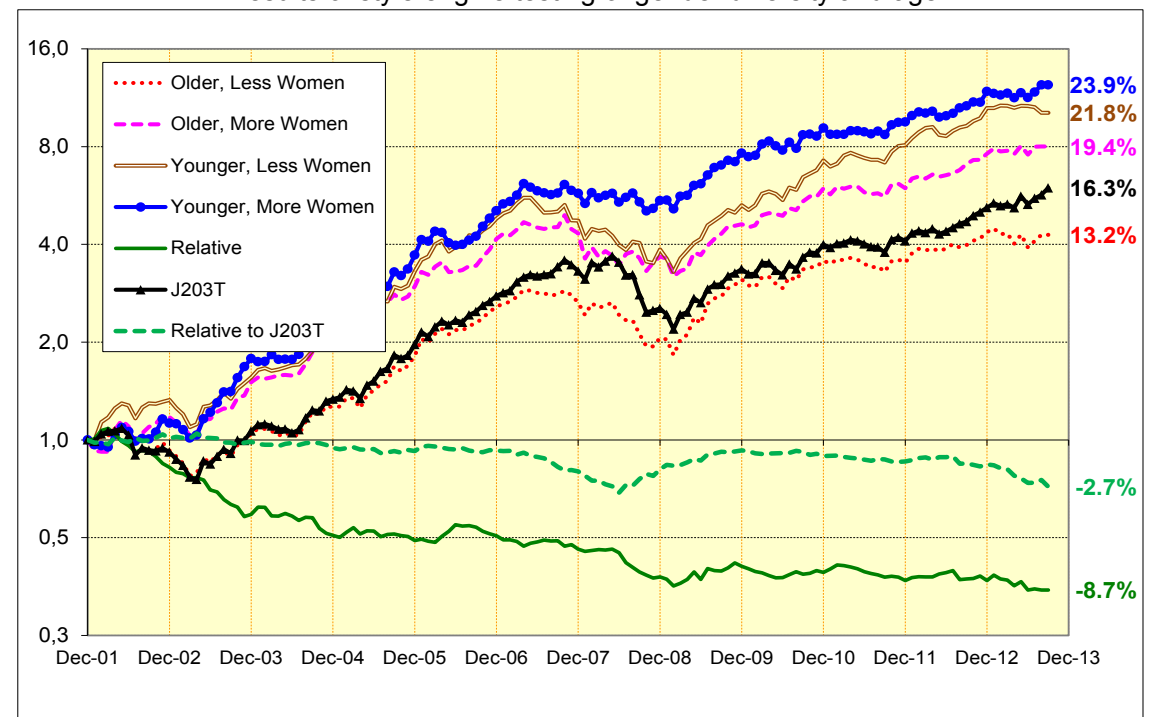


The style engine independently ranked all companies every month in terms of the percentage female representation on their boards and the average age of the boards. For each variable, the companies were divided into two portfolios as discussed earlier, and then combined into four distinct portfolios. The number of shares in each portfolio varied. The four portfolios created and updated monthly were: older boards with fewer women; older boards with more women; younger boards with fewer women; and younger boards with more women.

Figure 15 above illustrates noticeable performance differences between the different portfolios with the best performing portfolio outperforming the worst by nearly nine per cent CAGR, as indicated by the green price relative line (solid line at bottom of chart). This analysis confirms the results from previous tests of gender and age diversity, with companies with younger boards and more female representation performing better than those with older boards and less female representation. The results are significant due to the order of the portfolios' performance ranking.

\section{Discussion of results}

The primary research question, whether company financial performance is influenced by the level of diversity within boards, was investigated by identifying and testing for association between various diversity dimensions and company financial performance, using Muller and Ward's (2013) graphical time series approach. Four hypotheses were selected and tested, based on literature reviews, available data and time. Each is discussed below:

\subsection{Gender}

Results from the style engine analysis over the period, measured in terms of compound annual growth rates of total market returns, indicated that companies with more women on their board outperformed those with fewer women by 5.4 per cent. The outperformance was evident over the whole period, with companies with more women on their boards also outperforming the JSE's All Share Index by a CAGR of 4.6 per cent. The null hypothesis, $\mathrm{H}_{\mathrm{G} 0}$, that there is no association between the ratio of female representation on boards and company financial performance, is therefore rejected.

This result adds to the current academic discourse. The literature review uncovered mixed findings and of the 11 academic articles and three masters' studies commenting on board gender diversity and company performance, five found a positive link between increased gender diversity and company performance (Larkin et al., 2012; Lehobo, 2011; Mahadeo et al., 2012; Miller \& del Carmen Triana, 2009; Nguyen et al., 2012), seven found no significant association (Carter et al., 2010; Hili \& Affes, 2012; Matlala, 2011; Shukeri et al., 2012; Swartz, 2006; Van-Ness et al., 2010; Yasser, 2012) and two found slight negative associations (Jhunjhunwala \& Mishra, 2012; Lückerath-Rovers, 2013). Negative associations were explained by expanding on the difficulties of managing effective teams when increased diversity leads to increased differences in "attitudes and viewpoints" which "increases conflicts, reduces cohesion and hinders communication and coordination within the team" (Jhunjhunwala \& Mishra, 2012:78). Gender-specific behaviours were also considered, with one researcher contemplating that "companies with female directors payout relatively lower dividends than companies without female directors" (Lückerath-Rovers, 2013:503). Results showing no significant associations were also attributed to increased team inefficiencies: "valuable resources provided to the firm by women and ethnic minority directors may have been offset by the socialpsychological dynamics of the board such as exclusion or conflict" (Carter et al., 2010:411).

Positive associations between increased gender diversity and company performance are predicted by the theoretical frameworks of the agency-, resource dependency-, human capital- and signalling theories. As per the agency theory, increased levels of female representation can lead to increased board independence and improved governance if female directors act independently of their male counterparts, either by choice or due to inherent societal structures and norms. According to the resource dependency theory, increased diversity allows a broader network of different views to be incorporated with resultant effects on board and company decisions. Human 
capital theory can be linked to the effect seen in this test, as descriptive statistics have shown that together with an increase in the number of female directors, there was also an increase in the leveland number of qualifications. In addition, the lower average age of female directors and the increase in the number of female directors indicate that new thoughts and work methods are brought into the boardroom by female directors in South Africa.

The results support the research objectives as they clearly show that one of the diversity factors, namely gender, has a positive association with improved company financial performance.

\subsection{Race}

The test done on racial diversity did not produce the expected result and no association was found between increased levels of racial diversity and company performance. The different quintile portfolios' performance over the period was not consistent, with the portfolios' performance ranking changing numerous times over the period. The end result in terms of CAGRs was random with no pattern or trend in the rank of racial diversity portfolio performance evident. The result was however not negative: increased racial diversity was not associated with decreased company performance. The null hypothesis, $\mathrm{H}_{\mathrm{R} 0}$, that there is no association between the level of racial diversity on boards and company financial performance, is therefore accepted.

Five academic articles and one master's study commented on associations between racial diversity and company performance. Out of the six sources, five (Erhardt et al., 2003; Marimuthu, 2008; Miller \& del Carmen Triana, 2009; Shukeri et al., 2012; Swartz, 2006) found a positive link between racial diversity and company performance and only one (Carter et al., 2010) found no link. Positive associations were primarily explained by resource dependency- and human capital theory, with Shukeri et al. (2012:122) asserting that increased "racial diversity broadens knowledge, idea and experience through the range of information resources of different cultural backgrounds among the board members". Lack of positive results was ascribed by Carter et al. (2010:411) to the "offsetting effects of having women and ethnic minority directors" and because "innovation and creativity in decisions might be nullified by group conflict". The result from the test on racial diversity and company performance done in this report supports the view that increased racial diversity does not increase the effectiveness of boards and company performance.

\subsection{Age}

The style engine analysis of age of board members over the selected period provided a significant result and showed that companies with younger boards outperformed older boards by 7.8 per cent compound growth annually. As with the result of the gender diversity test, the test of age of board members showed that outperformance was evident over the whole period and companies constituting the optimal performing age portfolio significantly outperformed the JSE's All Share Index as well. The top three quintiles or the top 60 per cent companies of the descending ranked list of companies performed worse than the lowest 40 per cent companies over the period investigated. The association found was negative, with higher average ages of board members linked to reduced company financial performance. This result is also more pronounced than the gender diversity test result and suggests that age is more important than gender when appointing new board members. The null hypothesis, $\mathrm{H}_{\mathrm{A} 0}$, that there is no association between the average age of boards and company financial performance, is thus rejected.

Only three academic articles that commented on the effect of the age of board members on company performance were included in the literature review. Two (Jhunjhunwala \& Mishra, 2012; Van-Ness et al., 2010) indicated no association between age and company performance and only one (Mahadeo et al., 2012) found an association. The positive association was attributed to the fact that a younger board "can consider the various strategic and operational aspects in a more effective way and this is translated in terms of a significantly positive relationship between age diversity and performance" (Mahadeo et al., 2012:384). The same reasons are given for the lack of positive results as mentioned in the previous sections; namely, increased difficulties to manage and align teams with increased levels of diversity. 
The result of this test supports the resource dependency- and human capital theories. It might also link to signalling theory: for example, the market accepts younger boards as being more innovative and willing to take risks and enabling higher growth rates in future. This result supports the research objectives by showing that age has a positive association with improved company financial performance.

\subsection{Gender and age}

Combining the two diversity dimensions that showed significant associations with improved company performance into a single test delivered the expected results, confirming the strong association of both age and gender diversity dimensions with company performance. The end-state ranked portfolios confirmed the order of magnitude impact of the two diversity dimensions: age contributes more towards company performance than gender. The result showed that younger boards with more women performed better than older boards with fewer women. The portfolio comprising companies with fewer women on their boards and older boards performed visibly worse than the JSE's All Share Index - the only portfolio in all the tests to do so. The null hypothesis, $\mathrm{H}_{\mathrm{GA} 0}$, that there is no association between the level of combined gender and age diversity on boards and company financial performance, is rejected.

No literature that addressed this combined diversity scenario was included in the review, but results can be deduced from theories and explanations given for the two separate dimensions, as discussed above, and will not be repeated here.

\section{Conclusions}

The objective of this research report was to determine whether there is an association between diversity within boards and improved company financial performance.

Using total share returns and directors' demographic data from 40 listed companies over the period 2000 to 2013, equally weighted portfolios were constructed. By arranging companies in descending order on the basis of board constructs (viz: size, age, gender and diversity) and rebalancing these periodically, total portfolio returns were calculated and time series graphs constructed to rank the respective portfolios' performance.

Strong associations between increased gender diversity as well as decreased average age of board and improved company performance were found. However, no association between increased racial diversity and company performance was found. Positive results are mainly attributed to agency-, resource dependency, human capital and signalling theories. Increased diversity is seen to bolster independence and to lessen agency problems. Rising diversity levels enlarge boards' external networks, allowing diverse stakeholders' needs to be accommodated and limiting dependence on strategic resources. Human capital is increased as the collection of different skills and experiences grow when more diversity is introduced within boards. The diversity within a board is interpreted in different ways by different stakeholders, and changes in diversity levels are also seen as a signal to the market, with, for example, the appointment of younger directors perceived positively as a company becoming more innovative and competitive.

The results do not contradict previous studies on the topic, but are valuable as they provide additional support using a new, robust methodology. The identified diversity dimensions shown to be associated with improved company performance could be used to guide future board appointments or, alternatively, investors' share selections. Younger boards may lead companies towards being more competitive and are associated with better share price performance, while the strong association shown between increased gender diversity and company financial performance strengthens the case for equal gender representation (Xingwana, 2013). Although the same support for increased racial diversity was not found, the opposite is also not true, and notwithstanding the legal requirements, the moral and social reasons for increasing racial diversity on boards in South Africa remain sufficient cause to redress wrongs of the past. 
Suggestions for future research include increasing the sample size both longitudinally and in cross-section, as well as controlling for survivorship bias. Furthermore, an extended battery of independent variables measuring board diversity, as well as additional dependent variables measuring company performance, would enhance the study.

\section{References}

ADAMS, R.B., HERMALIN, B.E. \& WEISBACH, M.S. 2010. The role of boards of directors in corporate governance: A conceptual framework and survey. Journal of Economic Literature, 48(1):58-107. Available at: doi:10.1257/jel.48.1.58.

ARGOTE, L. \& GREVE, H.R. 2007. A behavioral theory of the firm - 40 years and counting: Introduction and impact. Organization Science, 18(3):337-349. Available at: doi:10.1287/orsc.1070.0280.

BERTOLT. 2009. An R function for the Blau index of diversity. Myowelt. Available at: http://myowelt.blogspot.com/2009/08/r-function-for-blau-index-of-diversity.html [accessed 2013-08-12]. BOSNER, K. 2007. Board composition, structure, and financial performance: An update. Journal of Applied Business Research, 23(4): 27-36.

BRYANT, P. \& DAVIS, C. 2012. Regulated change effects on boards of directors: A look at agency theory and resource dependency theory. Academy of Strategic Management Journal, 11(2):1-15.

CAMPBELL, K. \& MÍNGUEZ-VERA, A. 2008. Gender diversity in the boardroom and firm financial performance. Journal of Business Ethics, 83(3):435-451.

CARTER, D.A., D'SOUZA, F., SIMKINS, B.J. \& SIMPSON, W.G. 2010. The gender and ethnic diversity of US boards and board committees and firm financial performance. Corporate Governance: An International Review, 18(5):396-414.

CONNELLY, B.L., CERTO, S.T., IRELAND, R.D. \& REUTZEL, C.R. 2011. Signaling theory: A review and assessment. Journal of Management, 37(1):39-67. doi:10.1177/0149206310388419.

CURSEU, P.L., RAAB, J., HAN, J. \& LOENEN, A. 2012. Educational diversity and group effectiveness: A social network perspective. Journal of Managerial Psychology, 27(6):576-594. Available at: doi:10.1108/02683941211252437.

DALTON, D.R., DAILY, C.M., ELLSTRAND, A.E. \& JOHNSON, J.L. 1998. Meta-analytic reviews of board composition, leadership structure, and financial performance. Strategic Management Journal, 19(3): 269-290. Available at: doi:10.2307/3094100.

DALTON, D.R. \& DALTON, C.M. 2011. Integration of micro and macro studies in governance research: CEO duality, board composition, and financial performance. Journal of Management, 37(2):404-411.

DEZSÖ, C.L. \& ROSS, D.G. 2012. Does female representation in top management improve firm performance? A panel data investigation. Strategic Management Journal, 33(9):1072-1089. Available at: doi:10.1002/smj.1955.

DUTIES OF DIRECTORS. 2011, March. Deloitte \& Touche. Available at: http://www.deloitte.com/assets/ Dcom-SouthAfrica/Local\%20Assets/Documents/director duties.pdf [accessed 2013-10-10].

ERHARDT, N.L., WERBEL, J D. \& SHRADER, C.B. 2003. Board of director diversity and firm financial performance. Corporate Governance: An International Review, 11(2):102-111.

GAVETTI, G., GREVE, H.R., LEVINTHAL, D.A. \& OCASIO, W. 2012. The behavioral theory of the firm: Assessment and prospects. The Academy of Management Annals, 6(1):1-40. Available at: doi:10.1080/19416520.2012.656841

WILL EMPOWER WOMEN: XINGWANA. 2012. SABC News.com. Available at: http://www.sabc.co.za/news/a/bca741004c8bfe37bd5ebfe4e21497a9/Gender-Equality-Bill-will-empowerwomen:-Xingwana-20123108 [accessed 2013-04-24].

HAFSI, T. \& TURGUT, G. 2013. Boardroom diversity and its effect on social performance: Conceptualization and empirical evidence. Journal of Business Ethics, 112(3):463-479. Available at: doi:10.1007/s10551-012-1272-z.

HILI, W. \& AFFES, H. 2012. Corporate boards gender diversity and earnings persistence: The case of French listed firms. Global Journal of Business \& Management Research, 12(22):51-59.

JHUNJHUNWALA, S. \& MISHRA, R.K. 2012. Board diversity and corporate performance: The Indian evidence. IUP Journal of Corporate Governance, 11(3):71-79. 
KHAN, W. \& VIEITO, J.P. 2013. CEO gender and firm performance. Journal of Economics and Business, 67:55-66. Available at: doi:10.1016/j.jeconbus.2013.01.003.

KIM, I., PANTZALIS, C. \& PARK, J.C. 2013. Corporate boards' political ideology diversity and firm performance. Journal of Empirical Finance, 21:223-240. Available at: doi:10.1016/j.jempfin.2013.02.002. KING REPORT ON CORPORATE GOVERNANCE IN SA. (n.d.) The Institute of Directors in Southern Africa (IoDSA). Available at: http://www.iodsa.co.za/?page=kingIII [accessed 2013-07-27].

KNIGHT, D., PEARCE, C.L., SMITH, K.G., OLIAN, J.D., SIMS, H.P., SMITH, K.A. \& FLOOD, P. 1999. Top management team diversity, group process, and strategic consensus. Strategic Management Journal, 20(5):445

KOŹLAK, J., ZYGMUNT, A. \& NAWARECKI, E. 2013. Modelling and analysing relations between entities using the multi-agents and social network approaches, (arXiv:1303.6094).

LARKIN, M., BERNARDI, R. \& BOSCO, S. 2012. Board gender diversity, corporate reputation and market performance. International Journal of Banking and Finance, 9(1). Available at: http://epublications.bond. edu.au/ijbf/vo19/iss1/1 [accessed 2013-10-10].

LEHOBO, L. 2011. The relationship between gender diversity and corporate profitability: The top 100 companies on the JSE Ltd (MCom). University of Johannesburg, Johannesburg. Available at: https:/ujdigispace.uj.ac.za/handle/10210/8120 [accessed 2013-10-10].

LÜCKERATH-ROVERS, M. 2013. Women on boards and firm performance. Journal of Management \& Governance, 17(2):491-509. Available at: doi:10.1007/s10997-011-9186-1.

MAHADEO, J., SOOBAROYEN, T. \& HANUMAN, V. 2012. Board composition and financial performance: Uncovering the effects of diversity in an emerging economy. Journal of Business Ethics, 105(3):375-388.

MARIMUTHU, M. 2008. Ethnic diversity on boards of directors and its implications on firm financial performance. Journal of International Social Research, 1(4):431-445.

MATLALA, R.E. 2011. Board gender diversity and financial performance (MBA dissertation). University of Pretoria, Pretoria. Available at: http://upetd.up.ac.za/thesis/available/etd-07212012-170427/ [accessed 201310-10].

MCCARTER, M.W. \& SHEREMETA, R.M. 2013. You can't put old wine in new bottles: The effect of newcomers on coordination in groups. PLoS ONE, 8(1):e55058. Available at: doi:10.1371/journal.pone.0055058.

MILLER, T. \& DEL CARMEN TRIANA, M. 2009. Demographic diversity in the boardroom: mediators of the board diversity-firm performance relationship. Journal of Management Studies, 46(5):755-786. Available at: doi:10.1111/j.1467-6486.2009.00839.x

MULLER, C. \& WARD, M. 2013. Style-based effects on the Johannesburg Stock Exchange: A graphical time-series approach. Investment Analysts Journal, 77:67-82.

NGUYEN, T., LOCKE, S. \& REDDY, K. 2012. Do female directors add value? Evidence from an emerging market (SSRN Scholarly Paper No. ID 2179213). Rochester, NY: Social Science Research Network. Available at: http://papers.ssrn.com/abstract=2179213 [accessed October 2013].

NIELSEN, B.B. \& NIELSEN, S. 2013. Top management team nationality diversity and firm performance: A multilevel study. Strategic Management Journal, 34(3):373-382. Available at: doi:10.1002/smj.2021.

RHOADES, D.L., RECHNER, P.L. \& SUNDARAMURTHY, C. 2000. Board composition and financial performance: a meta-analysis of the influence of outside directors. Journal of Managerial Issues, 12(1):76. RODRÍGUEZ-DOMÍNGUEZ, L., GARCÍA-SÁNCHEZ, I.-M. \& GALLEGO-ÁLVAREZ, I. 2012.

Explanatory factors of the relationship between gender diversity and corporate performance. European Journal of Law and Economics, 33(3)-603-620. Available at: doi:10.1007/s10657-010-9144-4.

RUSHTON, M. 2008. A note on the use and misuse of the racial diversity index. Policy Studies Journal, 36(3):445-459.

SHUKERI, S.N., SHIN, O.W. \& SHAARI, M.S. 2012. Does board of directors' characteristics affect firm performance? Evidence from Malaysian public listed companies. International Business Research, 5(9). Availablel at: doi:10.5539/ibr.v5n9p120.

SOLANAS, A., SELVAM, R.J.M., NAVARRO, J. \& LEIVA, D. 2012. Some common indices of group diversity: Upper boundaries. Psychological Reports, 111(3):777-796. 
SRINIDHI, B., GUL, F.A. \& TSUI, J. 2011. Female directors and earnings quality. Contemporary Accounting Research, 28(5):1610-1644.

SWARTZ, N.P. 2006. Broad structure and company performance in South Africa (MCom). The University of the Witwatersrand, Johannesburg. Available at: http://wiredspace.wits.ac.za/handle/10539/1604 [accessed 2013-10-10].

VAN-NESS, R.K., MIESING, P. \& KANG, J. 2010. Board of director composition and financial performance in a Sarbanes-Oxley world. Journal of the Academy of Business \& Economics, 10(5):56-74.

XINGWANA. 2013. Bill to tackle inequality. News24, August 3. Available at: http://www.news24.com/ SouthAfrica/News/Xingwana-Bill-to-tackle-inequality-20130803 [accessed 2014-08-04].

YANG YANG \& KONRAD, A.M. 2011. Understanding diversity management practices: Implications of institutional theory and resource-based theory. Group \& Organization Management, 36(1):6-38. Available atL doi:10.1177/1059601110390997.

YASSER, Q.R. 2012. Effects of female directors on firms' performance in Pakistan. Modern Economy, 03(07):817-825. Available at: doi:10.4236/me.2012.37104. 
Appendix 1: Sample of 40 companies

\begin{tabular}{|c|c|c|c|c|}
\hline Rank & Code & Name & $\begin{array}{c}\text { Market cap } \\
\text { (Rm Jan 2005) }\end{array}$ & JSE sector name \\
\hline 1 & AGL & Anglo American plc & 2061 & Mining \\
\hline 2 & BIL & BHP Billiton plc & 1800 & Mining \\
\hline 3 & SAB & SABMiller plc & 984 & Beverages \\
\hline 4 & SBK & Standard Bank Group Ltd & 876 & Banks \\
\hline 5 & SOL & Sasol Limited & 812 & Oil \& Gas Producers \\
\hline 6 & MTN & MTN Group Ltd & 748 & Mobile Telecommunications \\
\hline 7 & FSR & Firstrand Ltd & 748 & Banks \\
\hline 8 & TKG & Telkom SA SOC Ltd & 605 & Fixed Line Telecommunications \\
\hline 9 & OML & Old Mutual plc & 549 & Life Insurance \\
\hline 10 & ANG & Anglogold Ashanti Ltd & 518 & Mining \\
\hline 11 & ASA & ABSA Group Ltd & 500 & Banks \\
\hline 12 & AMS & Anglo American Plat Ltd & 469 & Mining \\
\hline 13 & REM & Remgro Ltd & 457 & General Financial \\
\hline 14 & SLM & Sanlam Limited & 349 & Life Insurance \\
\hline 15 & GFI & Gold Fields Ltd & 337 & Mining \\
\hline 16 & IMP & Impala Platinum Hlgs Ltd & 333 & Mining \\
\hline 17 & NED & Nedbank Group Ltd & 287 & Banks \\
\hline 18 & $\mathrm{RMH}$ & RMB Holdings Ltd & 255 & Banks \\
\hline 19 & BVT & Bidvest Ltd & 255 & Support Services \\
\hline 20 & BAW & Barloworld Ltd & 236 & General Industrials \\
\hline 21 & NPN & Naspers Ltd -N- & 235 & Media \\
\hline 22 & IPL & Imperial Holdings Ltd & 222 & Industrial Transportation \\
\hline 23 & HAR & Harmony GM Co Ltd & 194 & Mining \\
\hline 24 & SAP & Sappi Ltd & 182 & Forestry \& Paper \\
\hline 25 & TBS & Tiger Brands Ltd & 162 & Food Producers \\
\hline 26 & LON & Lonmin plc & 152 & Mining \\
\hline 27 & SHF & Steinhoff Int HIdgs Ltd & 150 & Household Goods \\
\hline 28 & INP & Investec plc & 131 & General Financial \\
\hline 29 & PPC & PPC Limited & 127 & Construction \& Materials \\
\hline 30 & PIK & Pick 'n Pay Stores Ltd & 116 & Food \& Drug Retailers \\
\hline 31 & JDG & JD Group Ltd & 112 & General Retailers \\
\hline 32 & WHL & Woolworths Holdings Ltd & 106 & General Retailers \\
\hline 33 & DSY & Discovery Ltd & 101 & Life Insurance \\
\hline 34 & NPK & Nampak Ltd & 98 & General Industrials \\
\hline 35 & NTC & Netcare Limited & 87 & Health Care Equipment \& Services \\
\hline 36 & LBH & Liberty Holdings Ltd & 85 & Life Insurance \\
\hline 37 & APN & Aspen Pharmacare HIdgs Ltd & 84 & Pharmaceuticals \& Biotechnology \\
\hline 38 & MSM & Massmart Holdings Ltd & 83 & General Retailers \\
\hline 39 & TRU & Truworths Int Ltd & 83 & General Retailers \\
\hline 40 & SNT & Santam Limited & 82 & Nonlife Insurance \\
\hline
\end{tabular}

(The data set used was sourced from BFA McGreggor) 